\title{
$\mathrm{B}$ 형 간염 표면항원 음성/표면항체 양성인 광범위 큰 $\mathrm{B}$ 세포림프종 환자에서 Rituximab-CHOP 항암치료 후 발생한 $\mathrm{B}$ 형 간염바이러스 재활성화 1예
}

박한민, 서재용, 최청조, 김진희, 김범준, 정용설, 박충기

한림대학교 의과대학 한림대학교성심병원 내과

\section{A Case of Hepatitis B Virus Reactivation in a HBsAg-Negative and Anti-HBs- Positive Patient with Diffuse Large B-Cell Lymphoma after Rituximab plus CHOP Chemotherapy}

\author{
Han Min Park, Jae Yong Seo, Chung Jo Choi, Jin Hee Kim, Bum Jun Kim, Yong Seol Jeong, Choong Kee Park \\ Department of Internal Medicine, Hallym University Sacred Heart Hospital, Hallym University College of Medicine, Anyang, Korea
}

\begin{abstract}
The reactivation of hepatitis B virus (HBV) is well known complication among lymphoma patient related with chemotherapy. Rituximab is monoclonal antibody that targets B-lymphocytes for treatment of lymphoma and it increases reactivation of HBV. Although most of reactivation occurs in $\mathrm{HBV}$ carrier, it can also rarely occur when hepatitis $B$ surface antigen $(\mathrm{HBs} A g)$ is negative. Furthermore it is less frequently reported in lymphoma patient when $\mathrm{HBV}$ serology shows $\mathrm{HBsAg}$ is negative and anti-HBs is positive. We report a case of HBV reactivation following 6 cycle of rituximab plus CHOP (cyclophosphamide, doxorubicin, vincristine, prednisone) chemotherapy for diffuse large B-cell lymphoma in HBsAg negative/anti-HBs positive 58-year-old male, with a review of the literature.
\end{abstract}

Keywords: Hepatitis B virus; Lymphoma; Rituximab

\section{서 론}

$\mathrm{B}$ 형 간염은 전 세계적으로 분포되어 있으며 약 3 억 5 천 명 가량 이 감염자로, 이들은 비대상성 간염, 간경화, 간세포암의 발병위험 에 처해있다[1]. 급성 B형 간염의 자연경과에서 만성간염으로의 이 행은 감염 당시 연령과 관계가 깊으며 성인에서 발병한 경우 약 $5 \%$ 미만에서 만성화로 진행하고 나머지는 항 바이러스 항체와 세포독 성 $\mathrm{T}$ 림프구 등에 의해 간염바이러스가 제거되어 자연회복된다고 여겨졌다[2]. 하지만 급성 $\mathrm{B}$ 형 간염에서 회복된 지 수년이 지나 혈 청에서 항 바이러스 항체가 존재하는 경우에도 혈액 혹은 조직에
서 polymerase chain reaction (PCR) 등의 검출기법을 통해 바이러 스 DNA가 존재할 수 있으며[3], 이처럼 혈청에서 B형 간염 항원이 발견되지 않음에도 DNA가 혈청이나 간 등에 존재하는 것을 잠복 감염이라고 한다.

악성 림프종과 같은 혈액종양치료에 항암치료는 반응률과 관해 율이 높아 치료약제로 선택되고 있다. 최근에는 rituximab과 같은 표적치료제의 등장으로 치료의 효과는 증대되었지만 체내 면역체 계를 약화시키며 B형 간염의 재활성화의 가능성을 높였다.

저자들은 B형 간염 표면항원(hepatitis surface antigen, $\mathrm{HBsAg}$ ) 음성, B형 간염 표면항원에 대한 항체(antibody to hepatitis B surface 
antigen, anti-HBs)가 양성이었던 59세 남자 환자가 광범위 큰 B세포 림프종(diffuse large B-cell lymphoma)으로 6차례에 걸친 R-CHOP (rituximab, cyclophosphamide, doxorubicin, vincristine, prednisone) 항암치료 후 HBsAg 양성, anti-HBs 음성으로 혈청 전환과 함께 $\mathrm{B}$ 형 간염의 재활성화를 경험하였기에 문헌고찰과함께 보고하는 바이다.

\section{증 례}

59세 남자 환자가 내원 일주일 전부터 발생한 황달을 주소로 소화 기 내과 외래로 내원하였다. 동반증상으로 소화불량, 오심, 구토, 검 붉은 소변이 있었다. 30 년 전 급성 B형 간염을 않고 회복한 적이 있 었고, 고혈압 약 복용 중이었다. 환자는 10 개월 전 진단받은 광범위 큰 B세포 림프종으로 한림대학교 성심병원에서 6차례의 R-CHOP 항암치료를 받은 과거력이 있었다. 의무기록을 조회하였을 때 항암 치료 시작 전의 혈액검사는 $\mathrm{HbsAg}$ 음성, hepatitis B core antibody immunoglobulin G (anti-HBc IgG) 양성, anti-HBs 양성(역가 12.02 $\mathrm{mIU} / \mathrm{mL}$ ), antibody to hepatitis C virus (anti-HCV) 음성, aspartate aminotransferase (AST) $31 \mathrm{IU} / \mathrm{L}$ (정상범위, 8-38 IU/L), alanine aminotransferase (ALT) $24 \mathrm{IU} / \mathrm{L}$ (정상범위, 5-43 IU/L), 총 빌리루 빈 $0.29 \mathrm{mg} / \mathrm{dL}$ (정상범위, $0.2-1.2 \mathrm{mg} / \mathrm{dL}$ )였다.

황달에 대한 정밀검사를 위해 입원 후 시행한 혈액검사결과는 AST 1,985 IU/L, ALT 2,750 IU/L, 총 빌리루빈 $7.60 \mathrm{mg} / \mathrm{dL}$, 크레아 티닌 $0.94 \mathrm{mg} / \mathrm{dL}$ (정상범위, $0.7-1.2 \mathrm{mg} / \mathrm{dL}$ )였다. 간염바이러스에 대한 혈청검사를 시행하였고, hepatitis A antibody immunoglobulin M과 anti-HCV는 음성이었으나, 10 개월 전과 달리 $\mathrm{HBsAg}$ 는 양
성으로, anti-HBs는 음성의 결과를 보였다. 바이러스 증식 정도를 알아보기 위한 HBV-DNA는 7,560,000 IU/mL (정상범위, $20 \mathrm{IU} /$ $\mathrm{mL}$ 미만)로 측정되었으며, 입원 후 시행한 복부전산화 단층촬영에 서는 급성간질환에 따른 이차적인 변화로 생각되는 담낭벽의 부종 외에 만성간질환의 증거는 없었다(Fig. 1).

Rituximab 등 항암치료와 관련하여 B형 간염바이러스의 잠복감 염의 재활성화로 판단하였고 항 바이러스 제제로 tenofovir $300 \mathrm{mg}$ 을 투약하였다. 항 바이러스제 투약 후 간기능검사는 점차 호전을 보 였고, 퇴원 후 외래 경과 관찰 중 간기능검사는 모두 정상화되었다 (Fig. 2).

\section{고 찰}

악성종양 환자에서 $\mathrm{B}$ 형 간염의 재활성화에 대한 일반적인 정의 는 아직 없으나 비활성화 상태의 $\mathrm{HBsAg}$ 을 갖고 있는 보유자(inactive HBsAg carrier)나 관해 상태의 B형 간염 환자(resolved hepatitis B)에서 간조직 염증이 다시 생기는 것을 의미하며 치료 이전의 $\mathrm{HBV}-\mathrm{DNA}$ 수치에 비해 $1 \log$ 이상 바이러스 양이 증가하는 것이 재활성화의 일반적인 지표로 알려져 있다[4].

항암치료나 면역억제치료 등에 의해 유발된 B형 간염의 재활성 화는 여러 합병증을 초래할 수 있으며 개인의 의료비와 사회의 경 제적 부담을 증가시킬 수 있다. 무증상의 간기능 수치의 이상소견 에서부터 전격성 간염 등 다양한 합병증이 나타날 수 있고 치료의 진행 자체를 어렵게 할 수도 있기 때문이다.

일반적으로 $\mathrm{B}$ 형 간염의 회복에는 $\mathrm{T}$ 림프구가 관여하며 특히 간

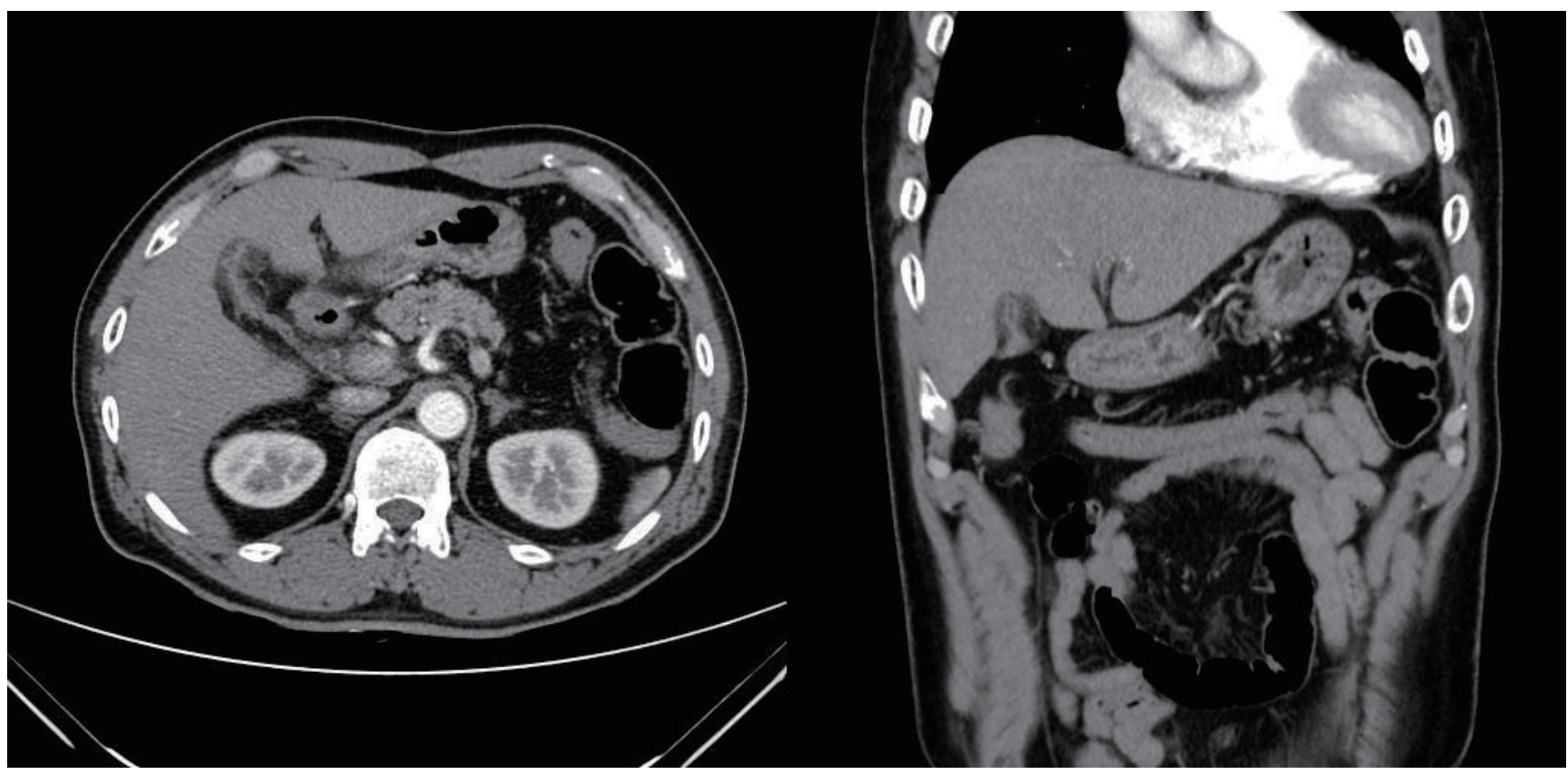

Fig. 1. Initial computed tomography images. Edematous wall thickening of gall bladder, suggesting secondary change related abnormal liver function. 


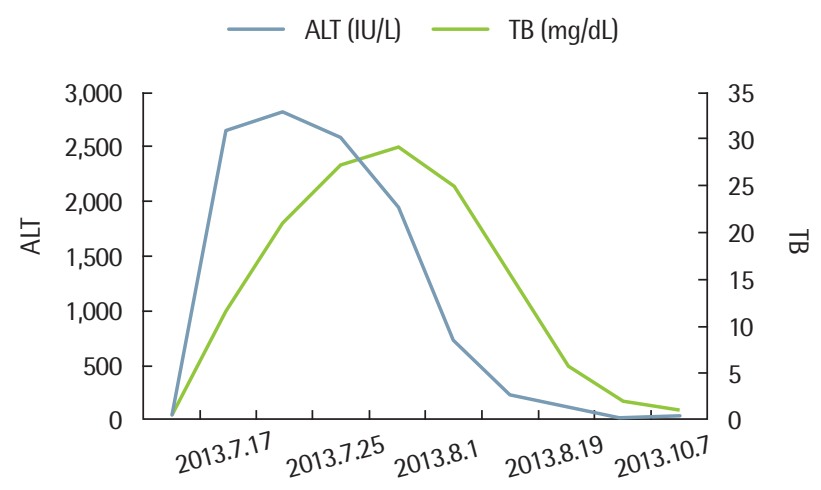

\begin{tabular}{lccc}
\hline & Pre-chemotherapy & Post-chemotherapy & After-tenofovir treatment \\
\hline HBsAg & - & + & + \\
Anti-HBs & + & - & - \\
HBeAg & - & - & - \\
Anti-HBe & + & + & + \\
HBV-DNA & Unchecked & $7.56 \times 10^{5}$ & $<20$ \\
\hline
\end{tabular}

Fig. 2. Changes in HBV serology marker, serum ALT and TB. The ALT, TB was normalized after tenofovir treatment which was initiated at July 19th, 2013. HBV, hepatitis B virus; ALT, alanine aminotransferase; TB, total bilirubin; $\mathrm{HBSAg}$, hepatitis B surface antigen; anti-HBs, hepatitis B surface antibody; HBeAg, hepatitis B e antigen; anti-HBe, hepatitis B e antibody.

세포 내에 존재하는 B형 간염바이러스에 특이적인 CD8+ T림프구 가 중추적인 역할을 수행한다[5]. 항암제나 면역억제제는 T림프구 등의 면역체계를 교란시키기에 B형 간염의 재발을 초래할 수 있었 을 것이라 추정된다. 이들 약물에는 대표적으로 cyclophosphamide, rituximab, dexamethasone 등이 있다.

항암치료나 면역억제치료 등에 의해 B형 간염의 재활성화는 여 러 사례가 보고되었고 HBsAg 양성 환자에서 이러한 치료 후 약 $20-50 \%$ 에서 B형 간염의 재활성화 가능성이 있다는 보고가 있다 [6]. $\mathrm{HBsAg}$ 가 음성인 경우의 재활성화는 상대적으로 적기는 하지 만 약 3-4\%로 보고되고 있으며 HBsAg이 양성인 군에 비해 간부전 이나 사망의 위험도는 더 높은 것으로 알려져 있다[7].

Oh와 Lee [8]는 rituximab 치료를 받았던 169 명의 환자군을 대 상으로 B형 간염의 재활성화에 대한 결과를 보고하였다. $\mathrm{HBsAg}$ 음성이며 anti-HBc 양성인 과거 B형 간염군 67 명 중 2 명이 재활성 화를 겪었으며 $\mathrm{HBsAg}$ 양성군과의 위험인자 비교 시 두 군 간 통계 적으로 유의한 차이를 보이는 인자는 $\mathrm{HBsAg}$ 여부와 $\mathrm{HBeAg}$ 여부 였다[8].

Jang 등[9]의 연구에서는 악성림프종으로 항암치료를 받은 196 명의 환자군을 대상으로 하였고 이 중 $\mathrm{HBsAg}$ 을 검사받았던 172 명 중 4명이 B형 간염 재활성화로 판명되었다. 이들은 $\mathrm{HBsAg}$ 이 양성 이었던 11명 중 3 명(27.2\%), HBsAg이 음성이며 anti-HBc가 양성인 15 명 중 1 명 $(6.6 \%)$ 이었다. 재활성화가 있었던 4명은 모두 anti-HBs
가 없었다[9].

상기 연구결과들 중 Oh와 Lee [8]의 연구는 HBsAg 음성이면서 anti-HBs 양성인 환자들의 재활성화 빈도를 명기하지 않았으며 Jang 등 [9]이 보고하였던 HBsAg 음성인 과거 감염 환자 1명은 anti$\mathrm{HBs}$ 가 없어 본 증례와는 차이를 보인다.

Anti-HBs에 대한 연구결과를 보면 Kusumoto 등[7]은 HBsAg이 음성인 군에서 항암치료 전 anti-HBs가 음성일 경우 재활성의 위험 도가 높아진다고 보고하였으며[7], 다른 보고에서는 rituximab을 포함한 항암치료 시 anti-HBs 역가가 낮아지며 역가가 $100 \mathrm{mIU} /$ $\mathrm{mL}$ 보다 낮은 경우 anti-HBs 소실률이 역가가 $100 \mathrm{mIU} / \mathrm{mL}$ 이상인 경우보다 많고 이로 인해 B형 간염의 재활성화 가능성이 높아질 수 있음을 보여 주었다[10].

비활성화된 B형 간염 보유자에서 항암치료나 면역억제치료 후 B 형 간염의 재활성화는 이전부터 잘 알려진 부작용으로 이에 대한 예방적 가이드라인을 제시하고 있다. 하지만 본 증례의 경우처럼 $\mathrm{HBsAg}$ 음성, anti-HBc IgG 양성의 환자에서는 아직 높은 수준의 권고안이 없는 실정으로 anti-HBs 역할 그리고 잠복감염 환자에서 anti-HBs 여부에 따른 재활성화의 위험에 대한 추가 연구가 필요하 리라 생각된다.

결론으로 본 증례와 같이 항암치료나 면역치료를 하기 전 $\mathrm{HBsAg}$ 음성, anti-HBc IgG 양성의 과거 B형 간염을 않았던 환자군에서 anti-HBs 양성을 보일지라도 특히 anti-HBs 역가가 낮은 경우에는 치 료 중 B형 간염바이러스의 재활성화의 가능성을 반드시 고려하여 치료 시작 후 주기적인 HBV-DNA 추적검사를 시행해야할 것이다.

\section{REFERENCES}

1. Liaw YF, Chu CM. Hepatitis B virus infection. Lancet 2009;373:582-92.

2. Tassopoulos NC, Papaevangelou GJ, Sjogren MH, Roumeliotou-Karayannis A, Gerin JL, Purcell RH. Natural history of acute hepatitis B surface antigen-positive hepatitis in Greek adults. Gastroenterology 1987;92:1844-50.

3. Rehermann B, Ferrari C, Pasquinelli C, Chisari FV. The hepatitis B virus persists for decades after patients' recovery from acute viral hepatitis despite active maintenance of a cytotoxic T-lymphocyte response. Nat Med 1996;2:1104-8.

4. Torres HA, Davila M. Reactivation of hepatitis B virus and hepatitis C virus in patients with cancer. Nat Rev Clin Oncol 2012;9:156-66.

5. Cheng AL, Hsiung CA, Su IJ, Chen PJ, Chang MC, Tsao CJ, et al. Steroidfree chemotherapy decreases risk of hepatitis $B$ virus (HBV) reactivation in HBV-carriers with lymphoma. Hepatology 2003;37:1320-8.

6. Yeo W, Lam KC, Zee B, Chan PS, Mo FK, Ho WM, et al. Hepatitis B reactivation in patients with hepatocellular carcinoma undergoing systemic chemotherapy. Ann Oncol 2004;15:1661-6.

7. Kusumoto S, Tanaka Y, Ueda R, Mizokami M. Reactivation of hepatitis B virus following rituximab-plus-steroid combination chemotherapy. J Gastroenterol 2011;46:9-16.

8. Oh MJ, Lee HJ. A study of hepatitis B virus reactivation associated with rituximab therapy in real-world clinical practice: a single-center experience. Clin Mol Hepatol 2013;19:51-9. 
9. Jang SJ, Jung YK, Baek HL, Yoon HH, Shin SK, Hong JS, et al. Reactivation of hepatitis B virus following systemic chemotherapy for malignant lymphoma. Korean J Med 2013;85:598-603.
10. Pei SN, Ma MC, Wang MC, Kuo CY, Rau KM, Su CY, et al. Analysis of hepatitis B surface antibody titers in B cell lymphoma patients after rituximab therapy. Ann Hematol 2012;91:1007-12. 